\title{
THE EFFECT OF Cd, Zn AND Fe ON SEED GERMINATION AND EARLY SEEDLING GROWTH OF WHEAT AND BEAN
}

\author{
TAOUFIK EL RASAFI, MOHAMED NOURI, SAID BOUDA, ABDELMAJID HADDIOUI*
}

Laboratory of Management and Valorization of Natural Resources Team of Genetic and Plant Biotechnology, University of Sultan MoulaySlimane, Faculty of Science and Techniques, Beni-Mellal, Morocco; e-mail: ahaddioui@ yahoo.fr

* Author for correspondence

\begin{abstract}
El Rasafi T., Nouri M., Bouda S., Haddioui A.: The effect of Cd, Zn and Fe on seed germination and early seedling growth of wheat and bean. Ekológia (Bratislava), Vol. 35, No. 3, p. 213-223, 2016.

This study was conducted to evaluate the effect of metals on wheat and bean species. The method uses seed germination and early seedling growth of these plants in the presence of various levels $(10,50,100,250,500,750$ and $1000 \mathrm{mg} / \mathrm{L})$ of Cadmium (Cd), Iron (Fe) and Zinc (Zn). The inhibition caused by these metals was depending on the concentration used, the metal itself and the plant species. The species had reduced seed germination, root and shoot lengths, tolerance index and percentphyto-toxicity with increasing concentrations of metals. Cadmium was determined to be the most inhibitory metal on these parameters. This metal affected significantly the germination, root and shoot length of the species tested, as well as the tolerance index and percentphytotoxicity starting from $50 \mathrm{mg} \mathrm{Cd} / \mathrm{l}$. Under the Iron stress, in general, the inhibition of germination and root length of wheat was reduced from $500 \mathrm{mg}$ Fe/l. The results showed also that the inhibitory effect of increase of $\mathrm{Zn}$ levels was seen in root, shoot and tolerance indices. The findings also revealed that the metal toxicity was as follow: $\mathrm{Cd}>\mathrm{Fe}>\mathrm{Zn}$. Regarding species, the results showed that bean seemed to be more tolerant to the increase of the three metals than wheat.
\end{abstract}

Key words: Triticum aestivum L., Phaseolus vulgaris L., heavy metals, seed germination, early seedling growth.

\section{Introduction}

Heavy metals are a serious ecological, nutritional and environmental problem. Heavy metals can occur naturally in rocks; they are released during the alteration of rocks, which become the geochemical background but rarely at toxic levels (Bourrelier, Berthelin, 1998). The natural concentrations of heavy metals in soils vary with the nature of the rock, its location and age. But the most important contamination of urban and agricultural soils by heavy metals was anthropogenic. Mining, manufacturing and the use of synthetic products (e.g., pesticides, paints, batteries, industrial waste, and applications of industrial or domestic sludge to the land) were the major sources of this kind of contamination. These elements have a strong negative effect on ecosystem. They can be non-essential trace elements, which are highly 
toxic and very harmful to all living beings (humans, animals and plants) even in trace concentrations (e.g., Cd, Pb and Hg) (Gang et al., 2013; Acharya, Sharma, 2014). While some of these elements such as $\mathrm{Cu}$ and $\mathrm{Zn}$ are essential for plant growth at low concentrations, and they start to be toxic at higher levels (Wintz et al., 2002). Similar to other organisms, plants are very sensitive to deficiency, and also to excess of heavy metals. The influence of these elements on plants is clearly seen in the inhibition of growth and death of the plant (Carlson et al., 1991). Heavy metals have been shown to affect different processes of plant functions, and clearly have a negative impact on seed germination. They can engender damage to the root system of plants (Singh, Thakur, 2014), by causing an oxidative stress by producing free radicals (Shah et al., 2010), or by replacing nutrient and essential metals (Henry, 2000). In general, the influence of trace elements on plants depends mainly on the heavy metal kind, the concentration applied and plant species.

The current study was carried out to improve our understanding of the ability of plants to grow in the presence of metallic stress, and to enhance our knowledge of plant reactions when they are exposed to different kinds and different doses of metal contamination. The experiment was based on the use of a range of different aqueous treatments of the three selected elements, $\mathrm{Cd}, \mathrm{Fe}$ and $\mathrm{Zn}$, for investigating their phytotoxic effects on the seed germination and seedling growth of a monocot: wheat (Triticum aestivum L.) and a dicot: bean (Phaseolus vulgaris L.).

\section{Material and methods}

Effect of $\mathrm{Cd}, \mathrm{Zn}$ and Fe on germination and seedling growth of wheat (Triticum aestivum L.) and bean (Phaseolus vulgaris) was investigated in laboratory conditions in Petri dishes. To avoid contaminations of bacteria and fungi, the seeds were surface-sterilised for $10 \mathrm{~min}$ with $1 \%$ sodium hypochlorite solution, rinsed in distilled water (1 time) and soaked in $70 \%$ ethanol for 1 min followed by 5 times washings with distilled water. To create metallic stress, 3CdSO4.8H2O, FeCl3.6H2OandZnSO4.7H2O were used in 7 concentrations $(10,50,100,250,500,750$ and 1000 $\mathrm{mg} / \mathrm{L}$ ) in 4 replications per treatment. 40 healthy seeds of each species were grown in Petri dishes containing one layer of Whatman filter paper in the bottom soaked previously with $5 \mathrm{ml}$ of solution. The distilled water was used as control for soaking the filter paper for each metal and each species. Petri dishes were kept in the oven at temperature of $23{ }^{\circ} \mathrm{C}$ for 6 days. In the end of the experiment, several parameters were measured:

- The germination percentage (GP) was calculated, as given by Tanveer et al. (2010):

$$
\mathrm{GP}=\frac{\text { Germinated seeds }}{\text { Total seeds }} \times 100
$$

- The relative germination rate (RGR) and the root and shoot length was measured, as well as the ratio between them.

- $\mathrm{RGR}=\frac{\text { Germination percentage in metal concentration }}{\text { Germination percentage in the control }}$

- The tolerance index (T.I.) was calculated using the formula given by Iqbal and Rahmati(1992).

$$
\mathrm{T} . \mathrm{I}=\frac{\text { Mean root length in metal solution }}{\text { Mean root length in control }} \times 100
$$

- $\quad$ The percent phytotoxicity (P.P.) was calculated according to Chou and Lin (1976) and Ray and Banerjee (1981).

$$
\mathrm{PP}=\frac{\text { Radicle length of Control }- \text { Radicle length of the Test }}{\text { Radicle length of Control }} \times 100 .
$$




\section{Statistical analysis}

The data obtained were submitted to one-way analysis of variance (ANOVA) using SPSS software (version 20.0). The percent germination data were arcsine transformed before conducting the statistical analysis to ensure the homogeneity of variance. Tukey test was used to separate the treatment means when significant difference was revealed among treatments at $\mathrm{p}=0.05$.

\section{Results}

Germination of seeds under heavy metals stress

The results obtained showed that the percentage of germination of seeds tested was related to the metal kind, the concentrations used and the species tested (Fig. 1). The cadmium concentrations in the medium was increased to significantly reduce the germination of the species seeds tested (Wheat: $\mathrm{F}=28.171, \mathrm{p}=0.000$; Beans: $\mathrm{F}=8.845 ; \mathrm{p}=0.000$ ). The most pronounced inhibitory effect of this metal was recorded for wheat, particularly when exposed to the highest concentrations. The increase of the concentration of Fe affected the germination of wheat significantly $(\mathrm{F}=$ $15.480 ; p=0.000)$. However, no significant effect of increased concentration of Fe was observed on the germination of beans $(\mathrm{p}=0.070)$. In contrast, the increase in the levels of Zinc didn't cause any significant effect on the germination of both the species.

\section{Relative germination rate}

The results corresponding to the RGR are summarised in Figure 2.
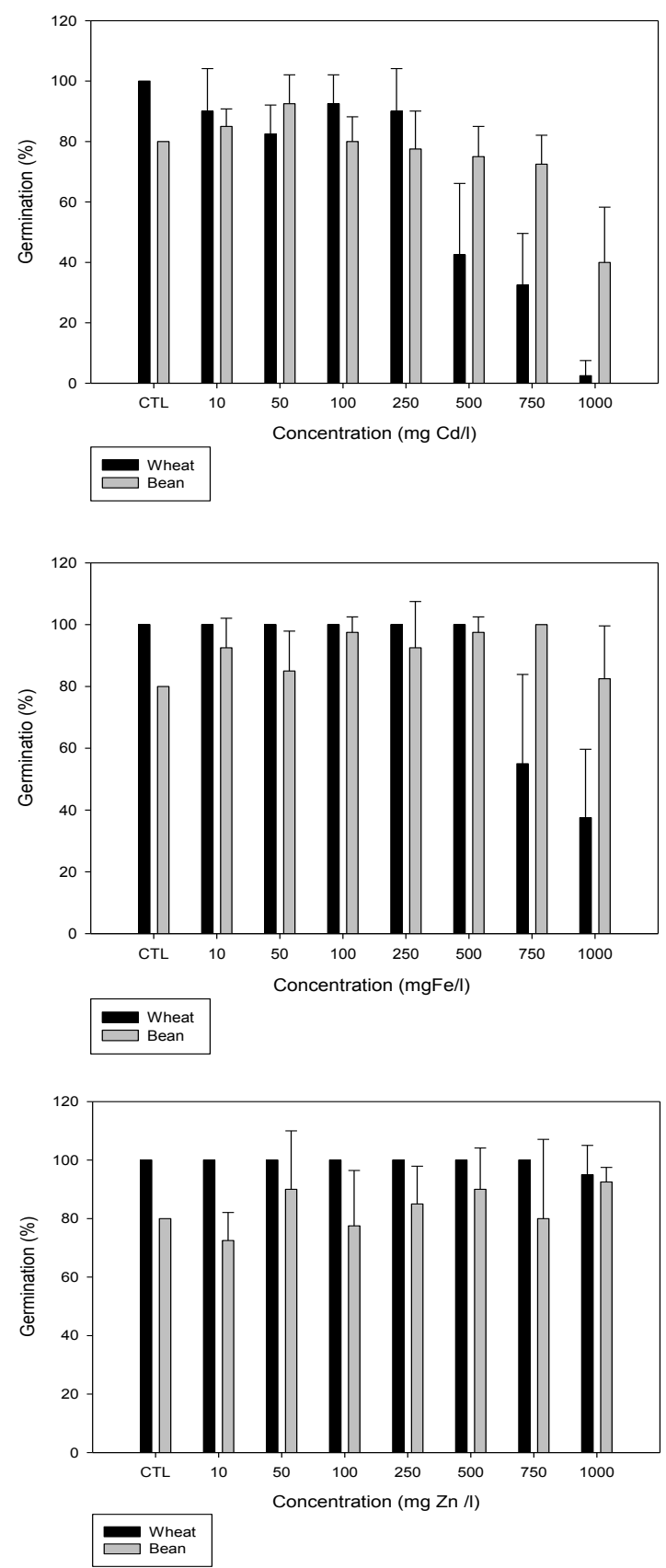

Fig. 1. Effect of $\mathrm{Cd}, \mathrm{Fe}$ and $\mathrm{Zn}$ on percentage of germination of Wheat and Bean. 


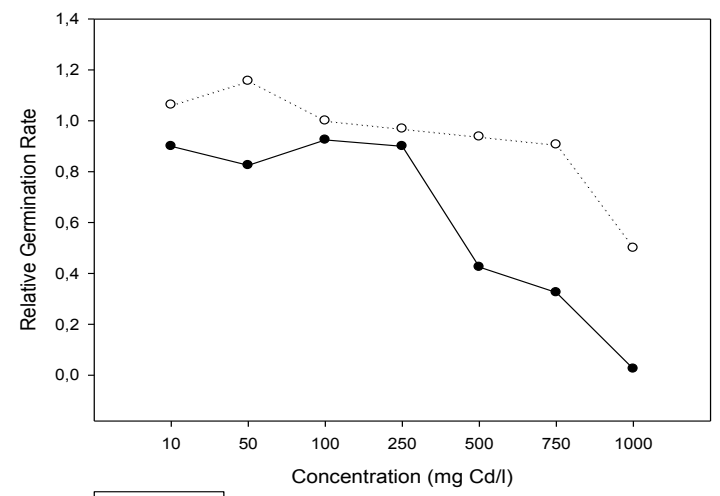

$\rightarrow$ Wheat
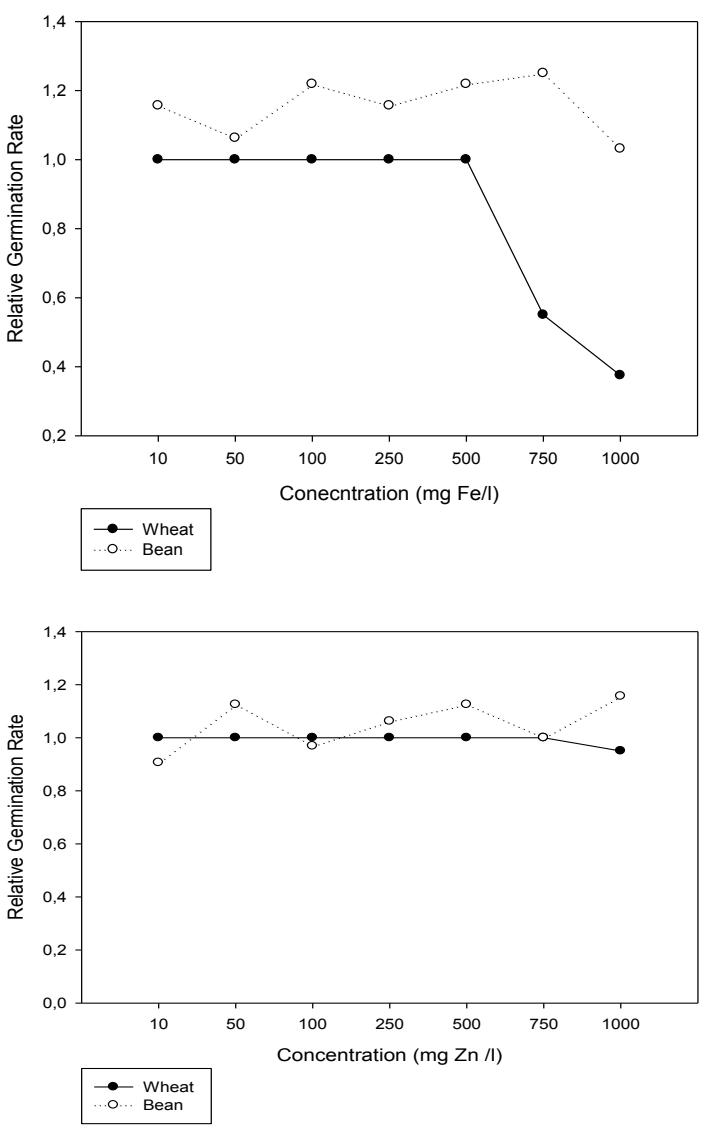

Fig. 2. Effect of Cd, Fe and $\mathrm{Zn}$ on relative germination rate of Wheat and Bean.
This result showed that clear inhibitory effect of wheat begins from 500 $\mathrm{mg}$ for $\mathrm{Cd}$ and $750 \mathrm{mg}$ for Fe. While the stress caused by Zn did not significantly reduce the RGR of this species, even with an increase in concentrations. As regard bean, the RGR was reduced only in the highest concentration of Cd $(1000 \mathrm{mg} / \mathrm{l})$.

\section{Effect of heavy metals on Root length}

Figure 3 presents the effects of $\mathrm{Cd}$, $\mathrm{Fe}$ and $\mathrm{Zn}$ on root length of wheat and beans. An increase in Cadmium levels significantly decreased the root length of both species (Wheat: $\mathrm{F}=$ 41.192; $\mathrm{p}=0.000$, Beans: $\mathrm{F}=18.433$; $\mathrm{p}=0.000$ ). This inhibition was apparent from the level of $50 \mathrm{mg} / \mathrm{l}$ of $\mathrm{Cd}$. In the highest concentration (500 and $1000 \mathrm{mg} / \mathrm{l}$ ), wheat seemed to be more affected. The same results were obtained with Iron and Zinc. The highest concentrations (500, 750 and 1000 $\mathrm{mg} / \mathrm{l})$ influenced clearly the length of the roots of wheat, while bean was less affected. On the other hand, the low levels of $\mathrm{Zn}(10$ and $100 \mathrm{mg} / \mathrm{l}) \mathrm{in}$ duced a stimulation of the root length of wheat.

Effect of heavy metals on Shoot length

The effect of different levels of $\mathrm{Cd}, \mathrm{Fe}$ and $\mathrm{Zn}$ on shoot length is summarised in Figure 4. The results showed that the lowest concentration of $\mathrm{Cd}$ $(10 \mathrm{mg} / \mathrm{l})$ stimulated the shoot length of wheat as compared to the control. After that, the increase of metal dose caused a significant decrease of the shoot length of both the species 

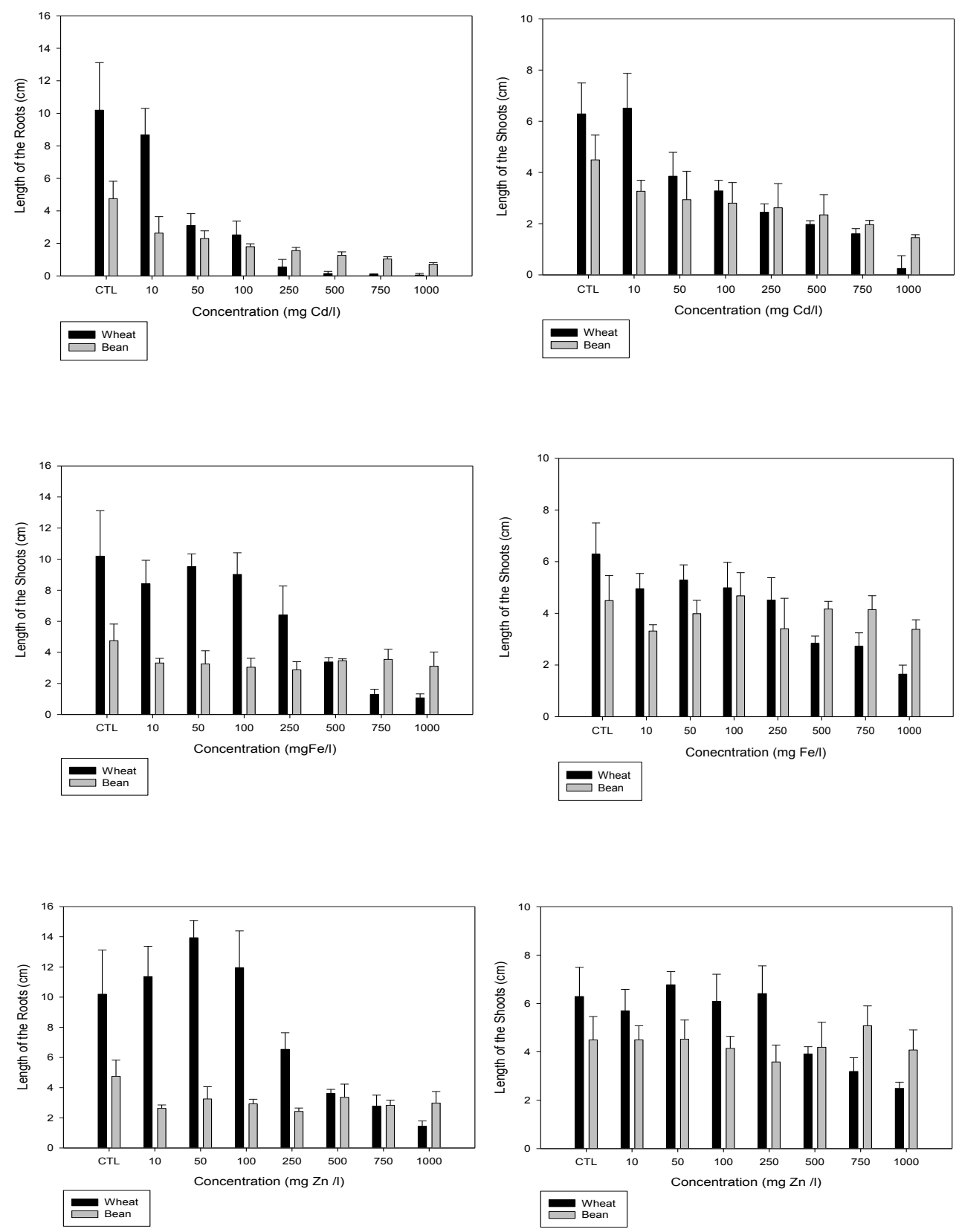

Fig. 3. Effect of $\mathrm{Cd}, \mathrm{Fe}$ and $\mathrm{Zn}$ on length of roots elongation of Wheat and Bean.

Fig. 4. Effect of $\mathrm{Cd}, \mathrm{Fe}$ and $\mathrm{Zn}$ on length shoots length of Wheat and Bean. 

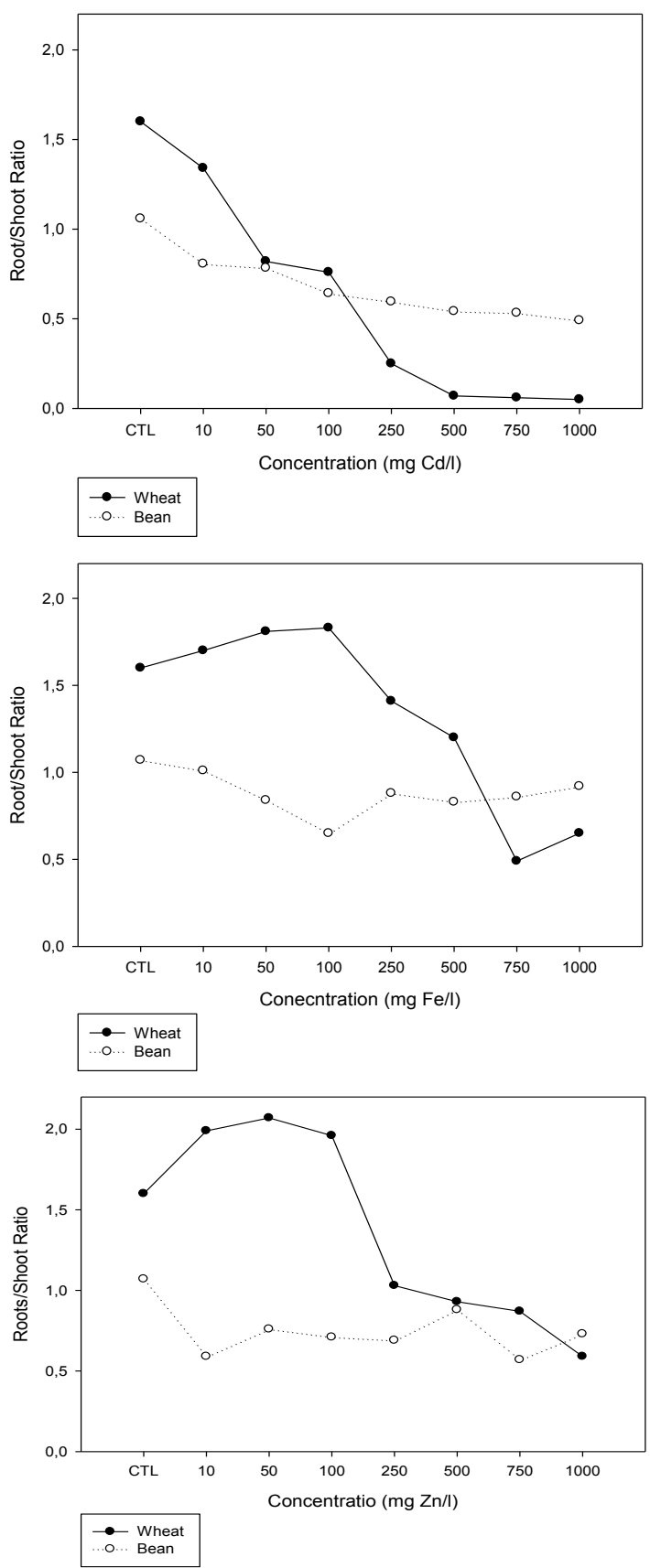

Fig. 5. Effect of $\mathrm{Cd}, \mathrm{Fe}$ and $\mathrm{Zn}$ on the root/shoot ratio of Wheat and Bean. $(\mathrm{p}=0.00)$. The inhibitory effect of $\mathrm{Cd}$ was more pronounced at higher concentrations $(1000 \mathrm{mg} / \mathrm{l})$, and wheat seemed to be more affected. However, the Fe and $\mathrm{Zn}$ treatment significantly reduced the shoot length of wheat (Fe: $\mathrm{F}=19.635 ; \mathrm{p}=0.000$ and $\mathrm{Zn}: \mathrm{F}=15.631 ; \mathrm{p}=0.000$ ), while no major changes were observed on shoots of bean.

\section{Effect of heavy metals on Root/Shoot Ratio}

The results of root/shoot ratio are presented in Figure 5. These results indicated that the increase of concentration of $\mathrm{Cd}$ caused a significant decrease of this parameter on wheat. The same result was observed for $\mathrm{Fe}$ and $\mathrm{Zn}$, where wheat was affected significantly in the presence of these metals in the growing medium.

\section{Tolerance index}

The results of the Tolerance Index are presented in the Figure 6 . The $\mathrm{Cd}$ affected the Tolerance Index of all species significantly $(\mathrm{p}=0.000)$, but bean seemed to be more tolerant to $\mathrm{Cd}$. The Tolerance Index of wheat was significantly reduced in presence of $\mathrm{Fe}$, while no significant effect on this parameter was recorded for bean $(\mathrm{p}=0.071)$. For this species, we could see a small increase of Tolerance Index for concentration above $250 \mathrm{mg} / \mathrm{l}$ as compared to the control. The response of the two species to $\mathrm{Zn}$ contamination was almost similar to their response in the presence of Fe. The lower doses of this metal 

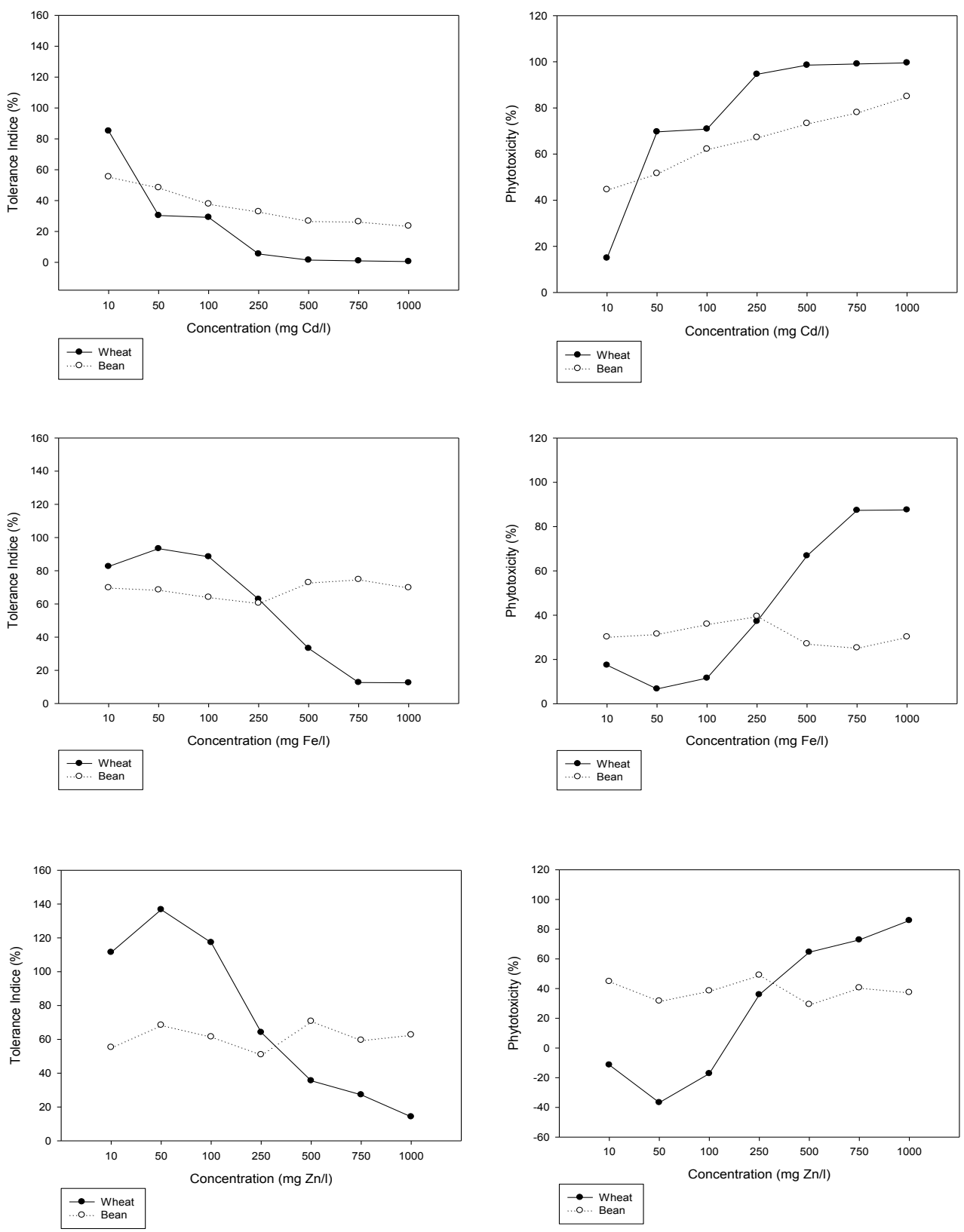

Fig. 6. Effect of $\mathrm{Cd}, \mathrm{Fe}$ and $\mathrm{Zn}$ on the tolerance index of Wheat and Bean.

Fig. 7. Effect of Cd, Fe and $\mathrm{Zn}$ on the percentage of phytotoxicity of Wheat and Bean. 
induced an increase of Tolerance Index of wheat (from $10 \mathrm{mg} / \mathrm{l}$ to $100 \mathrm{mg} / \mathrm{l}$ ) and the highest levels caused a clear decrease of this parameter (14.2). As observed in Fe treatment, bean had almost a stable level of Tolerance Index even when the concentrations of $\mathrm{Zn}$ were increased.

\section{Percent phytotoxicity}

The phytotoxicity of the three metals tested on root length of wheat and bean is presented in the Figure 7. The increase of Cd levels increased significantly the percent phytotoxicity on root length of both species $(\mathrm{p}<0.05)$. The lowest percent phytotoxicity was observed at the lowest concentration (14.92 and $44.58 \%$ for wheat and bean, respectively). Under Fe stress, the phytotoxicity of wheat was less than $20 \%$ at the three first concentrations $(10,50$ and $100 \mathrm{mg} / \mathrm{l})$, then it increased to almost $90 \%$ in $1000 \mathrm{mg} / \mathrm{l}$. As regard $\mathrm{Zn}$, the low doses (from 10 to $100 \mathrm{mg} / \mathrm{l}$ ) were more beneficial for the growth of wheat, while the highest levels were highly toxic to roots. Opposite to the effect on wheat, the increase of toxicity of both compounds (Fe and $\mathrm{Zn}$ ) didn't induce any clear effect on bean.

\section{Discussion}

In the present study, the effect of increasing levels of $\mathrm{Cd}$, Fe and $\mathrm{Zn}$ on germination and early seedling growth of wheat and bean was investigated. The results obtained showed that these metals affected the percentage of germination and early seedling growth of the species tested differently. The inhibitory effect of $\mathrm{Cd}$ and Fe was greatest on wheat germination. However, the bean seeds germination was reduced only in the presence of $\mathrm{Cd}$, while these seeds seemed to be more tolerant to Fe even at high metal concentrations. The negative effect of metals on seed germination was reported by different authors (Mathur et al., 1987; Iqbal, Mehmood, 1991; Athar, Masood, 2002; Li et al., 2005; Datta et al., 2011). Many other authors have explained the effect of metals on seeds germination as lowering of water uptake and transport (Bewley, Black, 1983; Becerril et al., 1989), or causing death or at least an embryonic damage (Wierzbicka, Obidzinska, 1998). About $\mathrm{Zn}$, this metal did not induce any significant inhibition on the germination of the two species. Peralta et al. (2001) obtained the same results using alfalfa at $40 \mathrm{ppm}$ of Zn. Kranner and Colville (2011) reviewed that the selection of plant species and the metal element can vary the degree to which metal toxicity affects negative germination. Some species can germinate at higher metal concentrations, which are highly toxic to other species.

Similar results were obtained for roots and shoots elongation. The results showed that the Cd was found to be the most toxic metal for wheat crop. This was also found in wheat and other species by other authors (Mathur et al., 1987; Iqbal, Mehmood, 1991; Shafiq et al., 2008; Moosavi et al., 2012; Shaikh et al., 2013). Regarding Iron, root and shoot length of wheat decreased significantly at the highest concentrations of Iron, when compared with the control. Nagajyoti et al. (2010) reported that Iron toxicity may be related to high Fe2+ uptake by roots and its transportation to shoots. These ions damaged membranes, DNA and proteins due to the production of the free radicals (Arora et al., 2002; De Dorlodot et al., 2005). Sinha et al. (1997) reported that Iron toxicity is accompanied with increase of oxidative stress in several plants. As regard Zinc, the two species studied showed similar results as obtained for Fe. The roots and 
shoots length was stimulated in the low levels brought out difference that roots and shoots were much longer with Zinc than with Iron. Similar results were previously reported in other studies for Cicer arietinum L. (Sharma S. et al., 2010) and Medicago sativa L. (Peralta et al., 2001). These authors reported that radical, hypocotyls length, root length and plant height increased when exposed to low concentration of $\mathrm{Zn}$. However, these two parameters decreased when excessive levels of $\mathrm{Zn}$ were applied. The inhibition of root and shoot growth by $\mathrm{Zn}$ is reported in different works (Choi et al., 1996; Ebbs, Kochian, 1997; Fontes, Cox, 1998; Lingua et al., 2008). In general, the roots of wheat and bean were seen to be more affected by an increase in $\mathrm{Cd}, \mathrm{Fe}$ and $\mathrm{Zn}$ doses than the shoots. This finding is in accordance with the result obtained by Lingua et al. (2008). They found that roots were inhibited by $70 \%$, while shoots were reduced only by $50 \%$ in the presence of $\mathrm{Zn}$. The inhibition of roots and shoots elongation caused by heavy metals can be due to their influence on cell division (Davies et al., 1991; Hargemeyer, Breckle, 1996), or their effect on cell wall elasticity and metabolic activities (Naseer et al., 2001). As we know, roots are the first part of the plant that comes in touch with contamination, they are more sensitive to toxicity by metals than shoots (Araujo, Monteiro, 2005; Shah et al., 2010; Yang et al., 2010; Yusuf et al., 2011). This sensibility reduced per consequence of the root/shoot ratio. Tariq Mahmood et al. (2007) reported that decrease in the root/shoot ratio may be caused due to structural and morphological changes of roots (absence of root hair, stunted and fibrous root growth and thickening or browning of roots) induced by metal.

On the other hand, this study showed that increase in $\mathrm{Cd}, \mathrm{Fe}$, and $\mathrm{Zn}$ concentrations had a significant decrease of metal toxicity tolerance of all seedlings (except beans when exposed to $\mathrm{Fe}$ ). The effect of $\mathrm{Cd}$ was more pronounced on seedlings of wheat than Fe and $\mathrm{Zn}$. Bean was less affected in the presence of the three metals. Wheat was less tolerant to the increase in the levels of these metals. The tolerance of bean in the presence of these metals may be due to the selectivity of their coats. The difference observed in the effect of metals may be related to the regulation of metal absorption due to the interspecies differences in seed coat structure (Tariq Mahmood et al., 2007). Wierzbicka, Obidziniska (1988) reported that the difference in the permeability of seed coats to metals leads to a range of seed germination inhibitions. In general, the presence of coats and covers in the bean seeds could minimise the influence of these elements on the seeds. The metal phytotoxicity discussed here is related to the species tested, and the metal and its doses used. The results indicated that the lowest concentrations of these metals induce a decrease of phytotoxicity, while high levels of metals increased the root phytotoxicity of selected plants. These finding were in concordance with the results obtained by Radha et al. (2010), Gang et al. (2013), Habtamu et al. (2013) and Shaikh et al. (2013) who reported that phytotoxicity of heavy metals on roots decreased at lower concentrations and increased at higher concentrations.

\section{Conclusion}

The results of this study indicated that the metals $\mathrm{Cd}$, Fe and $\mathrm{Zn}$ had different effects on seed germination and early seedling growth of wheat and bean. In general, Cadmium was more toxic than Iron and Zinc $(\mathrm{Cd}>\mathrm{Fe}>\mathrm{Zn})$. This study also showed that a high metal concentration $(750 \mathrm{mg} / \mathrm{l}$ and $1000 \mathrm{mg} / \mathrm{l})$ had a significant reduction in germination parameters. However, with low metal concentration $(10 \mathrm{mg} / \mathrm{l}$ to $100 \mathrm{mg} / \mathrm{l})$, a little inhibition was observed. On the 
other hand, this study showed that metal tolerance for germination seeds differ significantly between species. The bean was revealed to be more tolerant to metal stress than wheat. This study needed to be completed in order to establish the maximum amount of $\mathrm{Zn}$ and Fe that the plants can tolerate, and the ability of wheat and bean to germinate and grow in a mixture of these heavy metals.

\section{References}

Acharya, S. \& Sharma D.K. (2014). Study on the effect of heavy metals on seed germination and plant growth on Jatropha curcas. International Journal of Agricultural Science Research, 3(3), 031-034. http://academeresearchjournals.org/journal/ijasr

Araujo, A.S.F. \& Monteiro R.T.R. (2005). Plant bioassays to assess toxicity of textile sludge compost. Sci. Agric. (Piracicaba Braz.), 62(3), 286-290. DOI: 10.1590/S0103-90162005000300013.

Arora, A., Sairam, R.K. \& Srivastava G.C. (2002). Oxidative stress and antioxidative system in plants. Curr. Sci., 82, $1227-1338$.

Athar, R. \& Masood A. (2002). Heavy metal toxicity: Effect on plant growth and metal uptake by wheat, and on free living Azotobacter. Water Air Soil Pollut., 138, 165-180. DOI: 10.1023/A:1015594815016.

Becerril, J., lez-Murua, C.Gl., Munoz-Rueda, A. \& De Felipe M.R. (1989). Changes induced by cadmium and lead in gas exchange and water relations of clover and lucerne. Plant Physiol. Biochem., 27, 913-918.

Bewley, J.D. \& Black M. (1983). Physiology and biochemistry of seeds. New York: Springer-Verlag.

Bourrelier, P.H. \& Berthelin J. (1998). Contamination des sols par les éléments traces: les risquesetleurgestion. Paris: Lavoisier.

Carlson, L.C., Adriano, D.C., Sajwan, K.S., Abels, S.L., Thoma, D.P. \& Driver J.T. (1991). Effects of selected trace metals on germinating seeds of six plant speices. Water Air Soil Pollut., 59(3), 231-240. DOI: 10.1007/BF00211832.

Choi, J.-M., Pak, Ch-.H. \& Lee Ch.W. (1996). Micro nutrient toxicity in French marigold. J. Plant Nutr., 19, 901-916. DOI: $10.1080 / 01904169609365169$.

Chou, Ch.-H. \& Lin H.J. (1976). Autointoxication mechanism of Oriza sativa L. Phytotoxic effects of decomposing rice residues in soil. J. Chem. Ecol., 2, 353-367. DOI: 10.1007/BF00988282.

Datta, J.K., Bandhyopadhyay, A., Banerjee, A. \& Mondal N.K. (2011). Phytotoxic effect of chromium on the germination, seedling growth of some wheat (Triticum aestivum L.) cultivars under laboratory condition. International Journal of Agricultural Technology, 7(2), 395-402. http://www.ijat-aatsea.com

Davies, M.S., Francis, D. \& Thomas J.D. (1991). Rapidity of cellular changes induced by zinc in a zinc tolerant and non-tolerant cultivar of Festuca rubra L. New Phytol., 117, 103-108. DOI: 10.1111/j.1469-8137.1991.tb00949.x.

De Dorlodot, S., Lutts, S. \& Bertin P. (2005). Effects of ferrous iron toxicity on the growth and mineral composition of an interspecific rice. J. Plant Nutr., 28, 1-20. DOI: 10.1081/PLN-200042144.

Ebbs, S.D. \& Kochian L.V. (1997). Toxicity of zinc and copper to Brassica species: implications for phytoremediation. J. Environ. Qual., 26, 776-781. DOI: 10.2134/jeq1997.00472425002600030026x.

Fontes, R.L.F., \& Cox F.R. (1998). Zinc toxicity in soybean grown at high iron concentration in nutrient solution. J. Plant Nutr., 21, 1723-1730. DOI: 10.1080/01904169809365517.

Gang, A., Vyas, A. \& Vyas H. (2013).Toxic effect of heavy metals on germination and seedling growth of wheat. J. Environ. Res. Develop., 8(2), 206-213.

Habtamu, A., Derara, A. \& Tesfaye F. (2013). Effect of copper and zinc on seed germination, phytotoxicity, tolerance and seedling vigor of tomato (Lycopersicon esculentum L. cultivar Roma VF). International Journal of Agricultural Science Research, 2(11), 312-317. http://academeresearchjournals.org/journal/ijasr

Hargemeyer, J. \& Breckle S.W. (1996). Growth under trace element stress. In Y. Waisel, A. Ashel \& U. Kafkafi (Eds.), Plant roots. The hidden half (pp. 415-433). New York: Marcel Dekker.

Henry, J.R. (2000). In an overview of phytoremediation of lead and mercury. NNEMS Report (pp. 3-9). Washington, D.C.

Iqbal, M.Z. \& Mehmood T. (1991). Influence of cadmium toxicity on germination and growth of some common threes. Pak. J. Sci. Ind. Res., 34, 140-142.

Iqbal, M.Z. \& Rahmati K. (1992). Tolerance of Albizia lebbeck to Cu and Fe application. Ekológia (ČSFR), 11, 427-430.

Kranner, I. \& Colville L. (2011). Metals and seeds: biochemical and molecular implications and their significance for seed germination. Environ. Exp. Bot., 72, 93-105. DOI:10.1016/j.envexpbot.2010.05.005. 
Li, W., Khan, M.A., Yamaguchi, S. \& Kamiya Y. (2005). Effects of heavy metals on seed germination and early seedling growth of Arabidopsis thaliana. Plant Growth Regul., 46, 45-50. DOI: 10.1007/s10725-005-6324-2.

Lingua, G., Franchin, C., Todeschini, V., Castiglione, S., Biondi, S., Burlando, B., Parravicini, V., Torrigiani, P. \& Berta G. (2008). Arbuscular mycorrhizal fungi differentially affect the response to high zinc concentrations of two registered poplar clones. Environ. Pollut., 153, 137-147. DOI: 10.1016/j.envpol.2007.07.012.

Mathur, K.C. Srivastava, R.K. \& Chaudhary K. (1987). Effect of Cd and Cr metals on germination and early growth performance of Allium cepa seeds. Proc. Natl. Acad. Sci. India Sect. B (Biol. Sci.), 57, 191-196.

Moosavi, S.A., Gharineh, M.H., Afshari, R.T. \& Ebrahimi A. (2012). Effects of some heavy metals on seed germination characteristics of canola (Barassica napus), wheat (Triticum aestivum) and safflower (Carthamus tinctorious) to evaluate phytoremediation potential of these crops. J. Agric. Sci., 4(9), 11-19. DOI: $10.5539 /$ jas.v4n9p11.

Naseer, S., Nisar, A. \& Ashraf M. (2001). Effect of salt stress on germination and seedling growth of barley (Hordeum vulgare L.). Pakistan Journal of Biological Science, 4(3), 359-360. DOI: 10.3923/pjbs.2001.359.360.

Nagajyoti, P.C., Lee, K.D. \& Sreekanth T.V.M. (2010). Heavy metals, occurrence and toxicity for plants: a review. Environmental Chemistry Letters, 8, 199-216. DOI: 10.1007/s10311-010-0297-8.

Peralta, J.R., Gardea-Torresdey, J.L., Tiemann, K.J., Gomez, E., Arteaga, S., Rascon, E. \& Parsons J.C. (2001). Uptake and effects of five heavy metals on seed germination and plant growth in Alfalfa (Medicago sativa L.). Bull. Environ. Contam.Toxicol., 66, 727-734. DOI: 10.1007/s001280069.

Radha, J., Srivastava, S., Solomon S., Shrivastava, A.K. \& Chandra A. (2010). Impact of excess zinc on growth parameters, cell division, nutrient accumulation, photosynthetic pigments and oxidative stress of sugarcane (Saccharum spp.). Acta Physiol. Plant, 32, 979-986. DOI: 10.1007/s11738-010-0487-9.

Ray, M. \& Banerjee S.(1981). Detectionofphytotoxicityin irrigation waterpassingthroughanindustrialbeltof West Bengal. Proceedings of the VI.International Conference of Women Engineers and Scientists (pp. 59-65). Bombay.

Shafiq, M., Iqbal, M.Z. \& Athar M. (2008). Effect of lead and cadmium on germination and seedling growth of Leucaenaleucocephala. Journal of Applied Sciences and Environmental Management, 12(2), 61-66. DOI: 10.4314/ jasem.v12i3.55497.

Shah, F.R., Nasir, A., Masood, K.R., Peralta-Videa, J.R. \& Firozud Din Ahmad (2010). Heavy metal toxicity in plants. In M. Ashraf, M. Ozturk\& M.S.A. Ahmad (Eds.), Plant adaptation and phytoremediation (pp. 71-98). Springer. DOI: 10.1007/978-90-481-9370-7_4.

Shaikh, I.R., Shaikh, P.R., Shaikh, R.A. \& Shaikh A.A. (2013). Phytotoxic effects of heavy metals (Cr, Cd, Mn and Zn) on wheat (Triticum aestivum L.) seed germination and seedlings growth in black cotton soil of Nanded, India. Research Journal of Chemical Sciences, 3(6), 14-23. www.isca.in

Singh, K.J. \& Thakur A.K. (2014). Graviperceptional changes in the roots of cadmium treated soybean seedlings. Curr. Sci., 107(8), 1294-1298.

Sinha, S., Gupta, M. \& Chandra P. (1997). Oxidative stress induced by iron in Hydrilla verticillata (l.f) Royle: response of antioxidants. Ecotoxicol. Environ. Saf., 38, 286-291.DOI: 10.1006/eesa.1997.1598.

Sharma, S., Sharma, P., Datta, S.P. \& Gupta V. (2010). Morphological and biochemical response of Cicer arietinum L. var. pusa-256 towards an excess of zinc concentration. Life Science Journal, 7(1), 95-98. DOI:10.7537/ marslsj070110.17.

Tanveer, A., Rehman, A., Javaid, M.M., Abbas, R.N., Sibtain, M., Ahmad, A., Zamir, M.S., Chaudhary, K.M. \& Aziz A. (2010). Allelopathic potential of Euphorbia helioscopia L. against wheat (Triticum aestivum L.), chickpea (Cicer arietinum L.) and lentil (Lens culinaris Medic.). Turkish Journal ofAgriculture and Forestry, 34, 75-81.DOI: 10.3906/tar-0903-53.

Tariq, Mahmood, Islam, K.R. \& Muhammad S. (2007). Toxic effects of heavy metals on early growth and tolerance of cereal crops. Pak. J. Bot., 39(2), 451-462.

Wierzbicka, M. \& Obidzinska J. (1998). The effect of lead on seed imbibition and germination in different plant species. Plant Sci., 137, 155-171. DOI: 10.1016/S0168-9452(98)00138-1.

Wintz, H., Fox, T. \& Vulpe C. (2002). Responses of plants to iron, zinc and copper deficiencies. Biochem. Soc. Trans. 30, 766-768. DOI: 10.1042/bst0300766.

Yang, Y., Wei, X., Lu, J., You, J., Wang, W. \& Shi R. (2010). Lead-induced phytotoxicity mechanism involved in seed germination and seedling growth of wheat (Triticu maestivum L.). Ecotoxicol. Environ. Saf., 73, 1982-1987. DOI: 10.1016/j.ecoenv.2010.08.041.

Yusuf, M., Fariduddin, Q., Hayat, S. \& Ahmad A. (2011). Nickel: an overview of uptake, essentiality and toxicity in plants. Bull. Environ. Contam. Toxicol., 86, 1-17. DOI: 10.1007/s00128-010-0171-1. 